\title{
Integration of Burning and Picloram Pellets for Macartney Rose Control
}

\author{
R.A. GORDON, C.J. SCIFRES, AND J.L. MUTZ
}

Picloram pellets (5\% active ingredient [a.i.]) applied at $1.1 \mathrm{~kg} / \mathrm{ha}$ (a.i.) in June or September after burning Coastal Prairie in February resulted in excellent control of Macartney rose regrowth for at least two growing seasons. Picloram pellets (5\% or $10 \%$ a.i.) at 1 $\mathrm{kg} / \mathrm{ha}$ (a.i.) also effectively controlled Macartney rose when applied directly into the ash immediately after burning in the winter or early spring. Generally, there was no difference between the 5 and $10 \%$ formulations of picloram pellets applied at the same rate of active ingredient relative to Macartney rose control. Higher application rates (1.7 or $2 \mathrm{~kg} / \mathrm{ha}$ [a.i.]) tended to improve Macartney rose regrowth control on burned areas only slightly compared to that from $1 \mathrm{~kg} / \mathrm{ha}$ (a.i.) of the picloram pellets, regardless of formulation. Picloram pellet application extends the beneficial effects of prescribed burning on Macartney rose-infested rangeland. Prescribed burning eliminates the debris which prevents uniform grazing distribution and poses livestock handling problems following herbicide applications.

A native of China, Macartney rose (Rosa bracteata) was int roduced into the United States in the early 1800 's for use as hedge rows. The species spread rapidly and is now a serious range management problem on over 200,000 ha in southeast Texas, especially on the Coastal Prairie (Scifres 1975a).

Mechanical methods, herbicides, and prescribed burning have been evaluated for improvement of Macartney rose-infested rangeland but only limited success has resulted from use of any single method (Scifres 1975a). Shredding initially reduces the canopy but may scatter the Macartney rose canes, which ultimately increases the density of the woody plant since cane nodes can root in moist soil (Haas et al. 1970). Sprays of phenoxy herbicides such as 2,4-D ([2,4-dichlorophenoxy]acetic acid) are effective for Macartney rose control if several, successive, annual treatments are applied (Scifres 1980). Such multiple treatments are expensive and increase the risk of spray drift onto adjacent land supporting susceptible crops. Repeated herbicide applications seriously reduce the density and diversity of forbs that are important components of livestock and wildlife diets on these rangelands. Dead canes remaining after spraying Macartney rose pose a hindrance to livestock movement and handling. Moreover, Macartney rose regrowth trellising up the dead canes may achieve pretreatment heights within two growing seasons after herbicide application (Gordon and Scifres 1977).

Picloram (4-amino-3,5,6-trichloropicolinic acid) sprays applied alone or in combination with 2,4,5-T ([2,4,5-t richlorophenoxy] acetic acid), and picloram applied as pellets improves Macartney rose control compared to conventional sprays of phenoxy herbicides (Scifres 1975a, 1975b). Pellet formulations have several advantages over herbicide sprays, especially in reducing drift potential. Scifres (1975a) reported that picloram pellets applied at

Authors are former research assistant, professor, and assistant range scientist, Texas Agr. Exp. Sta. (Dep. Range Science), Texas A\&M Univ., College Station 77843 and Corpus Christi, 78410 . Senior author is currently research assistant, Department of Range and Wild life Management, Texas Tech Univ., Lubbock, 79409.

This report was approved by the Director, Texas Agr. Exp. Sta., as TA-16518. The efforts of J.R. Scifres in typing and preparing this manuscript, the participation of C.W. Hanselka who allowed use of data from result demonstrations herein, and the support of this research by P.H. Welder Ranches are appreciated.

Manuscript received January 22, 1981 .
$2.2 \mathrm{~kg} / \mathrm{ha}$ (a.i.) reduced Macartney rose live canopies by more than $80 \%$ at 1 year following application. However, brush control with the pellets is dependent on rainfall to facilitate root uptake of the herbicide (Scifres 1980). Therefore, woody plant response to the pellets is usually slower than following application of sprays.

Successful uniform canopy reduction of woody plants is also apparently dependent on uniform distribution of pellets to facilitate maximum root absorption (Scifres 1980). Uniform application of herbicide pellets with ground equipment may be hindered by the Macartney rose canopy cover, and the herbaceous cover may delay direct contact of the pellets with mineral soil.

Burning readily removes Macartney rose topgrowth and improves availability of herbacous forage to livestock (Gordon and Scifres 1977). However, suppression of Macartney rose with prescribed burning is temporary. For example, basal regrowth may be apparent within 2 weeks after burning in late winter and the new canes may elongate at an average rate of 7 to $8 \mathrm{~cm} /$ month (Gordon and Scifres 1977). Since use of broadcast sprays requires a well-developed canopy for maximum effectiveness (McCully et al. 1959; Haas et al. 1970; Scifres 1975a, 1975b, 1980), much of the range improvement gained from burning may be necessarily sacrificed if conventional herbicide treatments are used as a secondary practice. Therefore, a system was proposed which included the application of root-absorbed herbicide following prescribed burning of Macartney rose-infested range (Gordon 1976). The hypothesis was that burning to remove the herbaceous cover would facilitate application of herbicides as pellets, and that herbicide application as soon as possible following burning would effectively suppress development of Macartney rose regrowth. After considering previous research (McCully et al. 1959; Haas et al. 1970; Scifres 1975a, 1975b), this study was designed to evaluate the potential of picloram pellets following prescribed burning for improvement of Macartney rose-infested Coastal Prairie.

\section{Materials and Methods}

The research was conducted near Bloomington in Calhoun County, Texas. The study area was level to gently undulating, primarily Blackland range site, and typified by Lake Charles and Victoria clays (Udic Pellustert). Climax vegetation is tall grass prairie typical of the Gulf Prairies and Marshes (Gould 1975). Principal decreasers are little bluestem (Schizachyrium scoparium) and switchgrass (Panicum virgatum). Increasers include longtom (Paspalum lividum), brownseed paspalum (Paspalum plicatulum), knotroot bristlegrass (Setaria geniculata), and several low-growing species of Panicum and Dichanthelium. Herbaceous invaders include bushy bluestem (Andropogon glomeratus), broomsedge bluestem (Andropogon virginicus), and snow-on-the-prairie (Euphorbia bicolor). Bermudagrass (Cynodon dactylon), common on adjacent tame pastures, has escaped into portions of the study area. Macartney rose was the primary woody invader in association with scattered huisache (Acacia farnesiana) and honey mesquite (Prosopis glandulosa var. glandulosa). Foliar cover of Macartney rose varied from 35 to $75 \%$ at initiation of the research in 1975 (Gordon 1976). The study pastures were usually grazed by 
cattle from late spring to late fall. The initial stocking rate was 6.1 ha/ AU.

A 142-ha pasture was burned by ranch personnel on February 27, 1975. The pasture supported almost $4,000 \mathrm{~kg} /$ ha of fine fuel, and reduction of Macartney rose topgrowth exceeded $95 \%$. The burn was conducted with a wind speed of $16 \mathrm{~km} / \mathrm{hr}$, air temperature was $21^{\circ} \mathrm{C}$, and fine fule moisture (dry-wt basis) was $19 \%$. In June and September 1975 , picloram pellets (5\% a.i.) were applied at 1.1 $\mathrm{kg} /$ ha (a.i.) with a tractor-mounted spreader to 15.2 by $47.2-\mathrm{m}$ plots. The herbicide treatments were replicated three times in a randomized complete block design on each date. Since the entire pasture was burned, there was no opportunity to include unburned plots for comparison.

Three grazing exclosures, constructed of welded wire with 10 by $10-\mathrm{cm}$ openings, were established diagonally across each plot to evaluate forage production following treatment. Each exclosure was $1.5 \mathrm{~m}$ tall, $1.1 \mathrm{~m}$ in diameter, and secured by three metal rods driven into the ground. Live standing herbaceous crop was harvested to a $2.5-\mathrm{cm}$ stubble height from $0.25-\mathrm{m}^{2}$ sampling areas in the center of the exclosures on September 14, 1975, May 14, 1976, and June 14, 1977, separated into grasses and forbs, oven-dried, and weighed. The exclosures were moved after each harvest. Standing crop of Macartney rose regrowth was harvested to $2.5-\mathrm{cm}$ above ground line from 12 , equally spaced, $0.25-\mathrm{m}^{2}$ sampling areas on a line down the center of each plot on September 14, 1975, and May 14, 1976. Regrowth was then oven-dried and weighed.

In February 1976, ranch personnel burned an adjacent pasture under similar conditions and with results similar to those described for the one burned in 1975. Within 4 days following burning, picloram pellets ( 5 and $10 \%$ a.i.) were applied at $0,0.6,1.1$, and 1.7 $\mathrm{kg}$ / ha (a.i.) into the ash as described for the experiment installed in 1975. Herbicide treatments, replicated three times in a randomized complete block design, were applied to plots 31 by $21 \mathrm{~m}$. Adjacent unburned plots not treated with pellets were maintained for comparison to treated plots.

An alternative technique was employed for evaluation of the larger plots established in 1976, compared to methods for evaluating the first experiment. Using the line intercept method, foliar cover of live Macartney rose regrowth was recorded on June 15, 1977 and 1978. Two, 30.5-m lines (separated by $15 \mathrm{~m}$ ), were established diagonally across each plot. Interceptions spaced less than $1.5 \mathrm{~cm}$ apart on the line were recorded as continuous canopy cover and an interception of less than $1.5 \mathrm{~cm}$ was not recorded. This technique was also used in 1977 for evaluation of the smaller plot established in 1975 to enable comparison between experiments.

On March 7, 1979, another pasture supporting $3,360 \mathrm{~kg} / \mathrm{ha}$ of fine fuel was burned with a wind speed of approximately $16 \mathrm{~km} / \mathrm{hr}$. Air temperature was $23^{\circ} \mathrm{C}$ and fine fuel water content averaged $25 \%$. Macartney rose averaged $1 \mathrm{~m}$ tall and canopy cover was $46 \%$. The fire removed $95 \%$ of the woody plant canopy. On March 8 , 1979, picloram pellets were broadcast applied at 0,1 , or $2 \mathrm{~kg} / \mathrm{ha}$ (a.i.) to duplicate, 62 by $156-\mathrm{m}$ plots. Herbicide was applied in 6.2-m-wide swaths with a tractor-mounted spreader. The treatments were applied in the same manner to unburned Macartney rose in an adjacent pasture. On June 22, 1979, February 7,1980 , and August 24, 1980, foliar intercepts of Macartney rose were recorded along 10 or 20 , equally spaced, 20 -m lines laid at a right angle to direction of travel during herbicide application. Foliar intercepts were converted to percentage of pretreatment values before conducting analysis of variance based on a split plot arranged as a randomized complete block design.

On March 9, 1979, a 4.1-ha area supporting a heavy canopy cover of Macartney rose was burned near Port Lavaca, Texas. Fine fuel load averaged $3,360 \mathrm{~kg} / \mathrm{ha}$, the wind speed averaged about 19 $\mathrm{km} / \mathrm{hr}$, and the air temperature was $26^{\circ} \mathrm{C}$. Immediately following the burn, $1.1 \mathrm{~kg} /$ ha of picloram in pellets ( $10 \%$ formulation) were applied to 2-ha of the burned area as a demonstration of the burn-herbicide system. On September 2, 1980, canopy intercepts of live Macartney rose were recorded along five, randomly located, 31-m lines for each treatment.

\section{Results and Discussion}

\section{Experiment}

Macartney rose regrowth averaged approximately $21 \mathrm{~cm}$ tall when picloram pellets were applied in June 1975 after burning the previous February. Symptoms of herbicide phytotoxicity, epinasty, and chlorosis of young tissues, were not detectable until after the first significant rainfall $(5 \mathrm{~cm})$ at 30 days after application of the herbicide. From hcrbicide application until first evaluation in September $1975,26 \mathrm{~cm}$ of rainfall occurred on the study area. In September 1975, Macartney rose had no regrowth in plots treated with $1.1 \mathrm{~kg} /$ ha of picloram in June (Table 1). Conversely, burned plots not treated with herbicide supported uniformly distributed Macartney rose regrowth with an average standing crop of 694 $\mathrm{kg} /$ ha. Although Macartney rose regrowth on the burned plots was less than $0.5 \mathrm{~m}$ tall, the regrowth canes were rapidly elongating at the time of evaluation in September. Because of such rapid regrowth, Macartney rose canopy cover often develops such that additional burns are required within two or three growing seasons to prevent reductions in grass production (Gordon and Scifres 1977). Macartney rose regrowth rates were apparently slowed during the winter of 1975-76, which was relatively dry. Only $6.2 \mathrm{~cm}$ of rainfall (about $40 \%$ of the long-term average) were received from November through February.

Macartney rose regrowth in May 1976 occurred in only $8 \%$ of the samples where picloram pellets had been applied the previous June or September following burning in February. In comparison, there was a relatively uniform brush cover ( $80 \%$ frequency) on burned plots which were not treated with the herbicide. Consequently, Macartney rose standing crop in May 1976 was only 32 $\mathrm{kg} / \mathrm{ha}$ on plots burned and treated with picloram pellets in June 1975 compared to $1025 \mathrm{~kg} /$ ha on plots which were burned only (Table 1). Only trace amounts of Macartney rose topgrowth occurred in the samples taken in May 1976 from burned plots which were treated with picloram pellets in September 1975.

There was no difference in standing crop of herbaceous vegetation among treatments at evaluations conducted in September 1975 and May 1976 (Table 1). However, there was a trend toward increased grass standing crop on herbicide-treated areas, com-

Table 1. Standing crop (kg/ha) of Macartney rose and grasses (current season) following burning in February 1975 and application of picloram pellets (5\% formulation) at $1.1 \mathrm{~kg} / \mathrm{ha}$ (a.i.) in June or September 1975 to rangeland near Bloomington, Texas.

\begin{tabular}{|c|c|c|c|c|c|}
\hline \multirow[b]{3}{*}{$\begin{array}{l}\text { Date }(1975) \text { of picloram } \\
\text { pellet application }\end{array}$} & \multicolumn{5}{|l|}{ Standing crop ${ }^{1}$} \\
\hline & \multicolumn{2}{|c|}{ Macartney rose } & \multicolumn{3}{|c|}{ Grasses } \\
\hline & $\begin{array}{l}\text { September } \\
1975\end{array}$ & $\begin{array}{l}\text { May } \\
1976\end{array}$ & $\begin{array}{l}\text { September } \\
1975\end{array}$ & $\begin{array}{l}\text { May } \\
1976\end{array}$ & $\begin{array}{l}\text { June } \\
1977\end{array}$ \\
\hline $\begin{array}{l}\text { Untreated } \\
\text { June } \\
\text { September }\end{array}$ & $\begin{array}{r}694 \mathrm{c} \\
0 \mathrm{a} \\
-\end{array}$ & $\begin{array}{r}1025 \mathrm{~d} \\
32 \mathrm{~b} \\
\mathrm{~T} \mathrm{a^{2 }}\end{array}$ & $\begin{array}{c}4472 \mathrm{yz} \\
5119 \mathrm{z} \\
-\end{array}$ & $\begin{array}{l}1399 \mathrm{v} \\
2345 \mathrm{vw} \\
2138 \mathrm{v}\end{array}$ & $\begin{array}{l}1972 v \\
3702 \mathrm{xy} \\
3300 \mathrm{wx}\end{array}$ \\
\hline
\end{tabular}

IMeans within a standing crop type followed by the same letter are not significantly different $(P \leq .05)$ according to Duncan's multiple range test.

${ }^{2} \mathrm{~T}=$ trace, less than $10 \mathrm{~kg} / \mathrm{ha}$. 
Table 2. Macartney rose canopy interception (\%) in June 1977 and 1978 following burning and broadcast applications of 5 or $10 \%$ picloram pellets in February 1976 near Bloomington, Texas.

\begin{tabular}{lccc}
\hline \hline \multicolumn{2}{c}{ Picloram pellets } & & \\
\cline { 1 - 1 } $\begin{array}{l}\text { Formulation } \\
(\%, \text { a.i. })\end{array}$ & $\begin{array}{c}\text { Rate } \\
\text { (kg/ha, a.i. })\end{array}$ & Canopy interception (June) \\
\cline { 3 - 4 } & 0.6 & $9 \mathrm{bc}$ & 1977 \\
\hline 5 & 0.6 & $12 \mathrm{c}$ & $16 \mathrm{bb}$ \\
10 & 1.1 & $2 \mathrm{ab}$ & $9 \mathrm{ab}$ \\
5 & 1.1 & $12 \mathrm{c}$ & $16 \mathrm{~b}$ \\
10 & 1.7 & $1 \mathrm{a}$ & $5 \mathrm{a}$ \\
5 & 1.7 & $4 \mathrm{ab}$ & $8 \mathrm{ab}$ \\
10 & - & $44 \mathrm{e}$ & $51 \mathrm{~d}$ \\
Untreated & - & $25 \mathrm{~d}$ & $37 \mathrm{c}$ \\
Burned ony & - &
\end{tabular}

'Means within a column followed by the same letter are not significantly different $(P \leq .05)$ according to Duncan's multiple range test.

pared to those burned only, on those dates of evaluation. The differences in standing crop between the September and May evaluations reflect variation in rainfall. About $30 \mathrm{~cm}$ of rainfall were received from May to September 1975 whereas $14 \mathrm{~cm}$ occurred from January to May 1976. Thus, herbaceous production during the fall was as typically occurs on the Coastal Prairie but spring production was suppressed by dry growing conditions.

The differences in herbaceous standing crop were more pronounced in June 1977 than in May 1976 after initiation of the experiments in 1975. Grass standing crop on plots burned only was $1,972 \mathrm{~kg} /$ ha whereas plots treated with picloram pellets following burning supported an average of $2,400 \mathrm{~kg} /$ ha of herbaceous standing crop (Table 1). Macartney rose canopy cover in June 1977 averaged $29 \%$ on plots burned but not treated with herbicide. In comparison, burned plots treated with $1.1 \mathrm{~kg} / \mathrm{ha}$ (a.i.) of picloram pellets in June or September 1975 supported Macartney rose canopy covers of 2 to $3 \%$.

\section{Experiment}

Suppression of Macartney rose regrowth on plots burned and treated with picloram pellets in February 1976 (Table 2) was similar to the effects of the 1975 herbicide application (Table 1). Although no rainfall was received the month of treatment and the spring of 1976 was relatively dry, the remainder of the year was wet, resulting in an annual total rainfall of $80 \mathrm{~cm}$ on the study area. At 16 months after burning in February 1976, canopy cover of Macartney rose was $25 \%$ compared to $44 \%$ on unburned Coastal Prairie (Table 2). Moreover, all burned plots treated with picloram pellets in 1976, regardless of herbicide rate or percent active ingredient, supported less Macartney rose regrowth in June 1977 than did plots burned only. Macartney rose canopy cover was $9 \%$ on plots treated with $0.6 \mathrm{~kg} /$ ha (a.i.) of the $5 \%$ picloram pellets compared to canopy covers of $2 \%$ and $1 \%$ on plots receiving 1.1 and $1.7 \mathrm{~kg} /$ ha of the herbicide, respectively.

At 28 months after burning in February 1976, Macartney rose canopy cover was significantly less than on unburned areas but had increased by $12 \%$ since the evaluation 12 months earlier (Table 2). In June 1978, canopy cover on plots burned and treated with the herbicide pellets was less than on plots burned only. Although a trend for decreasing woody plant canopy cover with increasing herbicide rate existed, canopy cover was not different among application rates within a formulation or between formulations within an application rate of herbicide. Because of the rapid canopy replacement rate, the land owner reburned the pasture supporting the experiment in the winter 1979.

\section{Experiments}

Slightly more than $19 \mathrm{~cm}$ of rainfall were received on the study area during January and February prior to installation of prescribed burns in March 1979. From the time of herbicide application to first evaluation, $34 \mathrm{~cm}$ of rainfall occurred on the study area. By 3 months after burning and applying the $10 \%$ picloram pellets in March 1979, Macartney rose canopy reduction was essentially complete on both burned and unburned areas, regardless of herbicide rate (Table 3 ). In contrast, canopy reduction averaged $64 \%$ at the first evaluation of the plots burned only. At 11 and 18 months after treatment installation, canopy reduction of Macartney rose was $90 \%$ or greater, regardless of rate of picloram applied or whether the areas were burned or unburned. By 18 months after burning only, Macartney rose canopy reduction averaged $31 \%$. Thus, in this experiment, prescribed burning did not appear to augment control of Macartney rose with picloram pellets as has been reported with common goldenweed (Isocoma coronopifolia) (Mayeux and Hamilton 1979). However, removal of standing dead canes was considered a management advantage on burned areas.

On September 2, 1980, Macartncy rose canopy cover reduction averaged $63 \%$ on the pasture burned near Port Lavaca, Texas. In contrast, canopy cover was reduced by $98 \%$ on the a rea burned and treated with $1.1 \mathrm{~kg} /$ ha (a.i.) of the $10 \%$ picloram pellets (data not shown). Cane regrowth on the burned pasture averaged $0.9 \mathrm{~m}$ tall compared to an average Macartney rose height of $1.9 \mathrm{~m}$ on the untreated area. On the portion of the pasture which was treated with $1.1 \mathrm{~kg} /$ ha (a.i.) of picloram pellets immediately following burning, Macartney rose height averaged $0.2 \mathrm{~m}$.

\section{Conclusions}

Burning during winter dormancy reduces Macartney rose canopy cover, and growth of herbaceous vegetation begins earlier the following spring than on unburned rangeland (Gordon and Scifres 1977). However, Macartney rose rapidly regrows and usually must be reburned within 2 to 3 years to maintain range improvement, especially if post burn precipitation is average or greater. Also, repeated burning tends to promote a prostrate growth habit in the Maca rtney rose, making it more difficult to treat with conventional methods such as herbicide sprays compared to undisturbed stands. Picloram pellets applied at $2.2 \mathrm{~kg} /$ ha (a.i.) will cont rol over $80 \%$ of undisturbed Macartney rose but the dead standing canes pose problems to livestock handling and care, and offer trellis support for regrowth canes (Scifres 1975a).

Based on data herein, integration of prescribed burning with picloram pellet applications will extend the influence of burning, and eliminate the management problem posed by standing debris when picloram pellets are applied to unburned rangeland. The picloram pellets may be applied broadcast directly into the ash

Table 3. Macartney rose canopy cover reduction (\%) at various times after burning on March 7 and application of picloram pellets on March 8, 1979 , near Bloomington, Texas.

\begin{tabular}{|c|c|c|c|c|c|c|}
\hline \multirow{3}{*}{$\begin{array}{l}\text { Picloram rate } \\
\text { (kg/ha, a.i.) }\end{array}$} & \multicolumn{6}{|c|}{ Months after herbicide application' } \\
\hline & \multicolumn{2}{|c|}{3} & \multicolumn{2}{|c|}{11} & \multicolumn{2}{|c|}{18} \\
\hline & Burned & Unburned & Burned & Unburned & Burned & Unburned \\
\hline $\begin{array}{l}0 \\
1 \\
2\end{array}$ & $\begin{array}{r}64 \mathrm{c} \\
99 \mathrm{~d} \\
100 \mathrm{~d}\end{array}$ & $\begin{array}{r}0 \mathrm{a} \\
100 \mathrm{~d} \\
100 \mathrm{~d}\end{array}$ & $\begin{array}{l}46 \mathrm{bc} \\
98 \mathrm{~d} \\
100 \mathrm{~d}\end{array}$ & $\begin{array}{r}0 \mathrm{a} \\
90 \mathrm{~d} \\
96 \mathrm{~d}\end{array}$ & $\begin{array}{l}31 \mathrm{~b} \\
95 \mathrm{~d} \\
99 \mathrm{~d}\end{array}$ & $\begin{array}{r}3 \mathrm{a} \\
93 \mathrm{~d} \\
95 \mathrm{~d}\end{array}$ \\
\hline
\end{tabular}


within 1 to 4 days after burning in the winter or late spring, or in the fall following winter fires. In this study, there was little difference in the response of Macartney rose among the times of picloram pellet applications or whether the rangeland was burned. However, application of the pellets immediately following winter burning appears advantageous because (1) brush removed by the fires does not pose a hindrance to movement of machinery, and mulch accumulations and herbaceous plants do not prevent immediate contact of the herbicide pellets with mineral soil; (2) herbicide application can be completed before other management activities begin in the spring; (3) the herbicide is applied ahead of the spring rainy season; and (4) the herbicide application prevents rapid recovery of Macartney rose which should prolong the benefits of prescribed burning (reducing the frequency of burns required for brush management).

\section{Literature Cited}

Gordon, R.A. 1976. Burning/picloram combinations for Macartney rose control on the Texas Coastal Prairie. M.S. Thesis, Texas A\&M Univ. College Station. 73 p.

Gordon, R.A., and C.J. Scifres. 1977. Burning for improvement of Macartney rose-infested coastal prairie. Texas Agr. Exp. Sta. Bull. 1183.15 p.

Gould, F.W. 1975. Texas Plants. A checklist and ecological summary. Texas Agr. Exp. Sta. MP-585. 121 p.

Haas, R.J., S.K. Lehman, and H.L. Morton. 1970. Influence of mowing and spraying dates on herbicidal control of Macartney rose. Weed Sci. 18:33-37.

Mayeux, H.S., Jr., and W.T. Hamilton. 1979. Cool-season burns suppress common goldenweed. Proc. South. Weed Sci. Soc. 32:225.

McCully, W.G., G.o. Hoffman, and B.E. Jeter. 1959. Possibility of controlling Macartney rose. Texas Agr. Exp. Sta. Prog. Rep. 2093. 4 p.

Scifres, C.J. 1975a. Systems for improving Macartney rose infested coastal prairie rangeland. Texas Agr. Exp. Sta. MP-1225. 12 p.

Scifres, C.J. 1975b. Fall application of herbicides improves Macartney rose-infested coastal prairie rangelands. J. Range Managc. 28:483-486.

Scifres, C.J. 1980. Brush Management. Principles and Practices for Texas and the Southwest. Texas A\&M Univ. Press, College Station. 360 p.

\section{Application Invited for Position of Executive Secretary of Society for Range Management}

The Executive Secretary shall serve as the Chief Administrative Officer of the Society for Range Management; is accountable to the Board of Directors and is under the immediate supervision of the President.

Date Job to be Filled:

January 15,1983 , or as soon thereafter as selected candidate is available.

Salary:

Commensurate with experience and qualifications.

\section{Qualifications:}

Demonstrated ability in public relations and communication, both internal and external to the SRM.

Demonstrated ability in organization management and administration.

Desire and ability to serve SRM members and Sectionson an international basis.

Education and/or experience in range management or the renewable resource sciences that are basic to range management.

Effectiveness in working with volunteer organizations.

\section{Duties:}

To promote, conduct and supervise the affairs and programs of the SRM including:

1) Serving as a spokesman for SRM and its program and activities before other organizations and the general public.

2) Providing liaison and cooperation with other organizations having objectives, programs, or activities related to those of $\mathrm{SKM}$.

3) Developing significant programs to attract and retain members in the Society.

4) Developing and administering the annual budget of the Society in concert with the SRM Board of Directors.

5) Supervising the staff of the Society.

6) Being responsible for the maintenance of appropriate records of SRM activities, finances, and membership.

7) Providing necessary services to the Sections, Committees, Board of Directors, and membership of the Society.

\section{Equal Opportunity Employer:}

Applicants will be considered without discrimination for reasons such as age, race, religion, sex, or national origin.

\section{Applications:}

Applications will be evaluated beginning December 1, 1982. Applications will be receivable until the position is filled. Candidates should send a resume, three or more references, and a letter of application to the chairman of the Search Committee: Dr. S. Clark Martin, 4402 East Sixth Street, Tucson, AZ 85711. 